\title{
Compost spreading in Mediterranean shrubland indirectly increases biogenic emissions by promoting growth of VOC-emitting plant parts
}

\author{
Romain Olivier ${ }^{\mathrm{a}}$, Anne-Violette Lavoir ${ }^{\mathrm{a}}$, Elena Ormeño ${ }^{\mathrm{a}}$, Florent Mouillot ${ }^{\mathrm{c}}$, Stéphane Greff ${ }^{\mathrm{a}}$, \\ Caroline Lecareux ${ }^{\mathrm{a}}$, Michael Staudt ${ }^{\mathrm{b}}$, Catherine Fernandez ${ }^{\mathrm{a}, *}$ \\ a Aix-Marseille Université - Institut Méditerranéen d'Écologie et de Paléoécologie (UMR CNRS 6116-Campus St Charles, 13331 Marseille, France \\ ${ }^{\mathrm{b}}$ Département Fonctionnement des Ecosystèmes, Centre d'Ecologie Fonctionnelle et Evolutive (UMR IRD E' CNRS 5175), 1919 Route de Mende, 34293 Montpellier, France \\ ' IRD, Département Ressource et Environnement/Centre d'Ecologie Fonctionnelle et Evolutive (UMR IRD \& CNRS), 1919 route de Mende, 34292 Montpellier Cedex 5, France
}

Keywords:

Monoterpenes

Compost

Quercus coccifera

Rosmarinus officinalis

Cistus albidus

Growth

\begin{abstract}
A B S T R A C T
We investigated the effect of sewage sludge compost spreading on plant growth and leaf terpene emissions and content of Quercus coccifera, Rosmarinus officinalis and Cistus albidus in a Mediterranean shrubland. Measurements were performed during 3 consecutive summers on 2 different plots treated in 2002 or 2007 with 50 or 100 tons of compost per hectare, corresponding to observations carried out 2 months to 7 years after spreading. A slight nutrient enrichment of soil and leaves ( $R$. officinalis and $C$. albidus) was observed, especially for phosphorous. Terpene emissions were not affected by compost spreading, although they tended to increase on treated plots after 6 and 7 years for $R$. officinalis and C. albidus respectively. Terpene content was not affected by any compost treatment. Leaf and stem growth were significantly enhanced by compost spreading after 2 and/or 7 years in all species with little difference between doses. Total leaf biomass on the last growth units was increased by more than $50 \%$ in C. albidus and more than $90 \%$ in Q. coccifera. The results suggest that compost spreading in Meditteranean shrublands has no or little direct effect on leaf terpene emissions, but indirectly leads to their increase through leaf biomass enhancement. Simulation of terpene emissions at stand level revealed an increase of terpene fluxes ranging between 6 and 13\%, depending on the plant species. Overall, compost spreading was assessed to result in an emission rate of $1.1 \mathrm{~kg} \mathrm{ha}^{-1} \mathrm{y}^{-1}$ for a typical $Q$. coccifera shrubland, but can reach $2.6 \mathrm{~kg} \mathrm{ha}^{-1} \mathrm{y}^{-1}$ for a typical $R$. officinalis shrubland.
\end{abstract}

\section{Introduction}

Municipal sewage sludge production is constantly on the increase in phase with the growth of urban populations and the improvement of waste water collection systems (MSI reports, 2007). The uncontrolled dumping of these biosolids, rich in phosphorous (P), nitrogen $(\mathrm{N})$ and other plant nutrients, was prohibited in the European Union in 1999 (Council Directive, 1999/31/EC). Their utilization in cultivated lands, subject to farmer acceptance, is insufficient to exhaust stocks of municipal sewage sludge and, as a result, studying new ways of recycling sewage sludge has become a major issue in waste management. Sewage sludge can be composted, which reduces volume, stabilizes organic matter and decreases the risks of heavy metal and salt leaching (García et al., 1990). This higher value-added waste can then be incorporated into agricultural soils as an organic amendment or used to restore degraded natural soils, as an

\footnotetext{
* Corresponding author. Tel.: +33 413551222; fax: +33 413551151. E-mail address: catherine.fernandez@univ-provence.fr (C. Fernandez).
}

alternative to incineration (Navas et al., 1999). For the latter purpose, compost is only surface-applied to minimize soil and vegetation disturbance.

Natural Mediterranean soils often present low fertility levels which are primarily due to the limited thickness of these soils as a result of an intense erosion and low water content in summer. This dryness limits nutrient absorption capacity and slows down mineralization processes (Leirós et al., 1999). The low soil fertility is also due to recurrent fires, which consume organic matter and enhance nutrient leaching (Grogan et al., 2000). Because of their low organic matter content, Mediterranean soils generally present low water holding capacity. $\mathrm{N}$ and $\mathrm{P}$ are the main limiting elements for plant growth in these Mediterranean ecosystems (Archibold, 1995), both having critical importance in plant nutrition (Lambers et al., 1998). Hence, Mediterranean degraded soils offer ideal sites where sewage sludge could be beneficially recycled (Martinez et al., 2003). Several studies show that sewage compost increases soil fertility (Larchevêque et al., 2006), water holding capacity and plant growth and nutrient content (Martinez et al., 2003; Larchevêque et al., 2009). However, the possible long-term impact of compost 
spreading on ecosystem functioning and pollution is not sufficiently understood. Previous studies investigating the environmental impact of sewage sludge-based products in forests have mainly focused on plant nutrition, growth, and heavy metal accumulation caused by mostly non-composted material (Vaz and Goncalves, 2002; Fuentes et al., 2007).

Compost spreading in natural environments could also have a critical impact on emissions of Biogenic Volatile Organic Compounds (BVOCs) from the vegetation (Ormeño et al., 2009). BVOC emissions are involved in the formation of tropospheric ozone and secondary organic aerosols (Atkinson and Arey, 2003). This is of special concern in the Mediterranean region where critical $\mathrm{O}_{3}$ levels are recorded every year (European Environment Agency, 2009) and significant BVOCs are emitted from forests and shrublands (Owen et al., 2001; Ormeño et al., 2007a). BVOCs can be constitutively emitted by vegetation or induced by stresses such as herbivore attacks (e.g. Staudt et al., 2010). Furthermore, BVOC emissions are involved in plant defences against abiotic stresses such as heat and ozone (e.g. Vickers et al., 2009).

Spreading of compost rich in nutrients may affect the plants' capacity to produce BVOCs. Fertilization experiments show a positive (Lerdau et al., 1995; Possell et al., 2004), negative (Fares et al., 2008), or variable effect (Rosenstiel et al., 2004; Blanch et al., 2007) on foliar BVOC emissions, depending on plant species, type and dose of nutrients, and experimental conditions. Likewise, nutrient supply can exert a positive (Lerdau et al., 1995), negative (Kainulainen et al., 1996) or no effect (Heyworth et al., 1998; Litvak et al., 2002) on leaf terpene content. Investigations on the effect of compost spreading have so far found either no change (Ormeño et al., 2009) or an increase in leaf terpene concentrations (Tanu et al., 2004; Hussein et al., 2006) and variable effects on leaf terpene emissions, depending on the dose and timing of the treatments (Ormeño et al., 2009).

In the present study we aimed to assess the short- and long-term effect of sewage sludge compost spreading in a Mediterranean shrubland on leaf terpene emissions and content from Quercus coccifera L., Rosmarinus officinalis L. and Cistus albidus L.. Plant growth and nutrition were also studied to assess the fertilizing effect of compost and its indirect effect on BVOC emissions via potential changes in leaf biomass, the major source of BVOCs.

\section{Material and methods}

\subsection{Species and experimental site}

Three typical Mediterranean species were selected representing different types of BVOC emitters. Q. coccifera releases monoterpenes but does not possess specialized structures to store them (Niinemets et al., 2002). Its emissions depend on the ongoing biosynthesis that is influenced by light and temperature, similarly to isoprene emissions. For species that possess storage organs (R. officinalis and C. albidus; Ormeño et al., 2007b), a major fraction of their BVOC emissions are expected to be mainly controlled by temperature due to their volatilization, even though it cannot be ruled out that some BVOCs may be light dependent too (Niinemets et al., 2004).

All 3 plant species are highly abundant in plateau of Arbois (Provence Southern France; 5818960E-438299100N in WSG-84 Norm), where the study took place: $Q$. coccifera (70\%), R. officinalis (20\%) and C. albidus (10\%). The experimental site is a degraded shrubland, under Mediterranean climate (hot dry summers and cool wet winters), with a Rendoll calcareous soil, a very heterogeneous structure and variable depth (Larchevêque et al., 2006). At this site compost was spread at 2 blocks on 2 dates: the first block consisting of nine $50 \times 10 \mathrm{~m}$ plots was treated in July 2002, the second block consisting of nine $10 \times 10 \mathrm{~m}$ plots was treated in May 2007. All plots were randomly arranged and surrounded by natural untreated shrubland. In both blocks, compost was spread at two different dosages: 3 plots at 50 t.ha $^{-1}$ (D50), 3 plots at 100 t.ha $^{-1}(\mathrm{D} 100)$ (Fig. 1). Three plots without treatment were also taken into account (controls) (Fig. 1). The compost, made from green waste, pine bark and municipal sewage sludge in identical proportions, was the same for the 2 spreading dates. The quality of the compost met the French legal standards (NFU44-095) for pathogenic microorganisms, organic trace elements and trace metals (Larchevêque et al., 2006).

Soil properties and plant nutrition status were monitored on a monthly basis from 2002 to 2004 (see also Larchevêque et al., 2006, 2009) and again during the BVOC sampling campaign. Decadal global radiation, daily precipitation and daily temperature were recorded at a nearby weather station (Meteo France).

\subsection{Sampling and measurement protocol}

Collection of soil and plant material, as well as plant emission measurements, were performed in early summer during three consecutive years: 2ndJuly 2007, 23rdJune 2008, and 24thJune 2009. Each sampling campaign was carried out over 5 consecutive days. For technical reasons, no soil sampling could be undertaken in July 2007 on the plots spread in 2002. Also, emission data from C. albidus on plots spread in 2007 are lacking for D50 in 2008.

\subsection{Study of monoterpene emissions and content}

BVOC emissions were measured on intact twigs of $Q$. coccifera, $R$. officinalis and Calbidus, randomizing the 3 treatments of the 2 blocks between 10 a.m. and 2 p.m. Two or 3 individuals per species were sampled on the plots of each spreading block (i.e. 6 or 9 replicates per treatment per spreading date). BVOC measurements, always collected on different individuals, were performed using a dynamic headspace system similar to that described in Ormeño et al. (2009), with a few differences: (i) at least $1 \mathrm{~h}$ before measurement, the oven

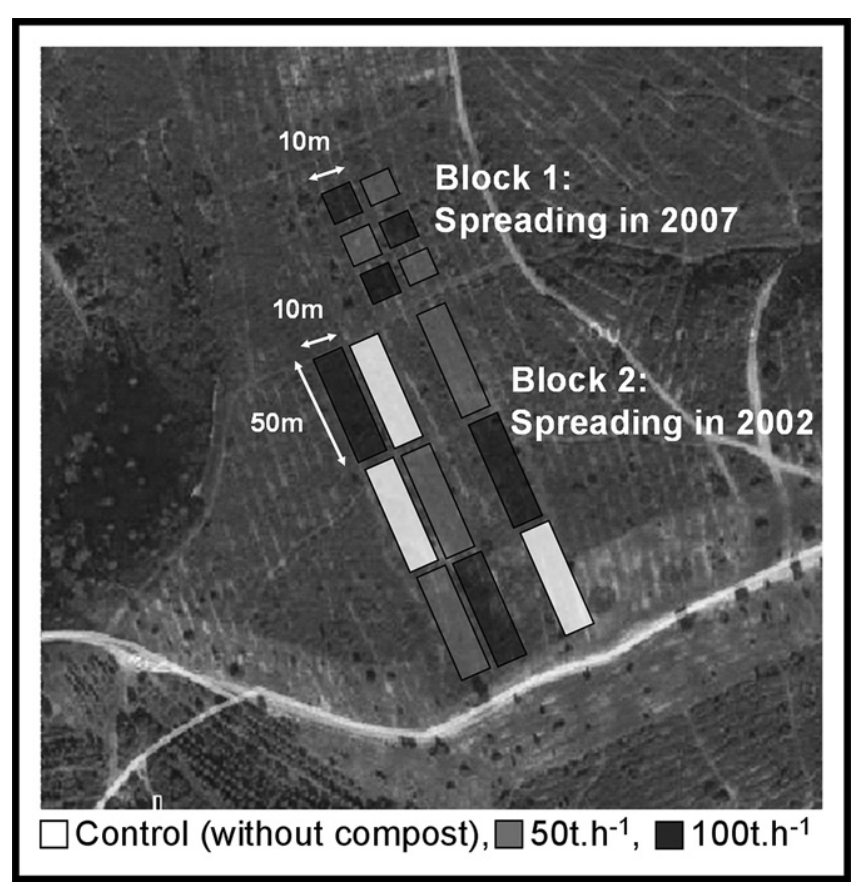

Fig. 1. Experimental design of compost spreading at the Arbois site (Provence, France). The two blocks correspond to the two spreading periods (2002 and 2007). 
bag (Nalophan ${ }^{\circledR}$ ) used as enclosure was carefully set around a healthy and sun-exposed twig without closing it, and (ii) a small fan was introduced into the dynamic enclosure to homogenize the atmosphere. Subsequently the bag was closed before starting the measurement. Since terminal twigs were always used, BVOC sampling was mainly done on mature current-year leaves, especially for $Q$. coccifera and C. albidus, which rarely keep past-year leaves on their twigs, as observed through these campaigns.

BVOC emissions were measured by sampling BVOCs from the headspace on Tenax cartridges. Tenax cartridges were analysed using the analytical system described in Olivier et al. (2011). Emission rates were normalized for short-term temperature and light effects using the algorithms of Guenther et al. (1993). BVOCs emitted from $Q$. coccifera were normalized to standard temperature $\left(30^{\circ} \mathrm{C}\right)$ and PPFD (1000 $\mu \mathrm{mol}$ photons $\left.\mathrm{m}^{-2} \mathrm{~s}^{-1}\right)$ values using the algorithm for isoprene emissions, while BVOCs emitted from $R$. officinalis and $C$. albidus were normalized to standard temperature $\left(30^{\circ} \mathrm{C}\right)$ using the algorithm for monoterpene emissions of VOC storing plant species. Hereafter, normalized and un-normalized emission rates are referred to as $E s$ and, $E$, respectively.

Foliar BVOCs were extracted from the same twigs used for emission sampling after lyophilization. The extraction was performed according to the method described in Llusià and Peñuelas (2000) and Ormeño et al. (2007b). Extracted BVOCs were identified and quantified using the same analytical system as that used in Ormeño et al. (2007b).

\subsection{Leaf and soil nutrient analyses}

After BVOC sampling, leaves of each twig were cut off, lyophilized, and reduced to powder with a ball mill, before being analyzed in terms of nutrients. Soil samples were taken a few $\mathrm{cm}$ under the litter-compost layer, corresponding to the mineral soil horizon, taking care not to include compost fragments. Three soil samples were randomly collected on each plot before analysis. The soil was oven-dried at $60{ }^{\circ} \mathrm{C}$ for $48 \mathrm{~h}$, sieved $(2 \mathrm{~mm})$ and ground in a ball mill. Leaf and soil N content were analyzed with a Flash EA 1112 Elemental Analyzer (Thermo Finnigan, Milan, Italy). Leaf P and potassium (K) content as well as soil available $\mathrm{P}$ (Olsen method) and extractable $\mathrm{K}$ content were analyzed by the Laboratoire Centre Atlantique (France) with an Inductively Coupled Plasma method (Olivier et al., 2011).

\subsection{Water status measurement}

Predawn xylem water potential was measured every 2 or 3 weeks from May 2008 to September 2008, and sporadically in June 2009. This was done using a pressure chamber (PMS Instrument Co. Corvallis, Oregon. USA) connected to a $\mathrm{N}_{2}$ tank. Measurements were performed on other individuals than those used for BVOC sampling to prevent any injury effect on the emissions rates. Three to 5 twigs were harvested (each twig taken from a different plant) in each plot, representing between 9 and 15 measurements per treatment.

\subsection{Growth measurement}

Twigs were collected on 10 individuals per species on each plot in February 2010, allowing assessment of growth 2 and 7 years after compost spreading. The method - adapted from Misson et al. (2011) - consisted of measuring wood dry mass (DM), length and largest diameter on the last growth unit (n). Wood volume was assessed by multiplying the basal diameter of the stem by its length. For each species, we determined the number of leaves, measured their DM and calculated their leaf mass per area ratio (LMA) on the last main growth unit of the twig. We counted the number of ramifications corresponding to the same last bud break (on the n-1 growth unit) for $C$. albidus and $Q$. coccifera. For $R$. officinalis the n-1 growth unit was barely definable and, as a result, we counted the ramifications of its last growth unit (n). For C. albidus and Q. coccifera, an estimation of the total emitting biomass on the last growth units of the twig was calculated by multiplying the leaf DM of the last growth unit by the total number of axes developed during the same flush (number of ramifications +1 ), assuming that leaf biomass is similar among ramifications. Results were expressed as the variation compared to control treatment.
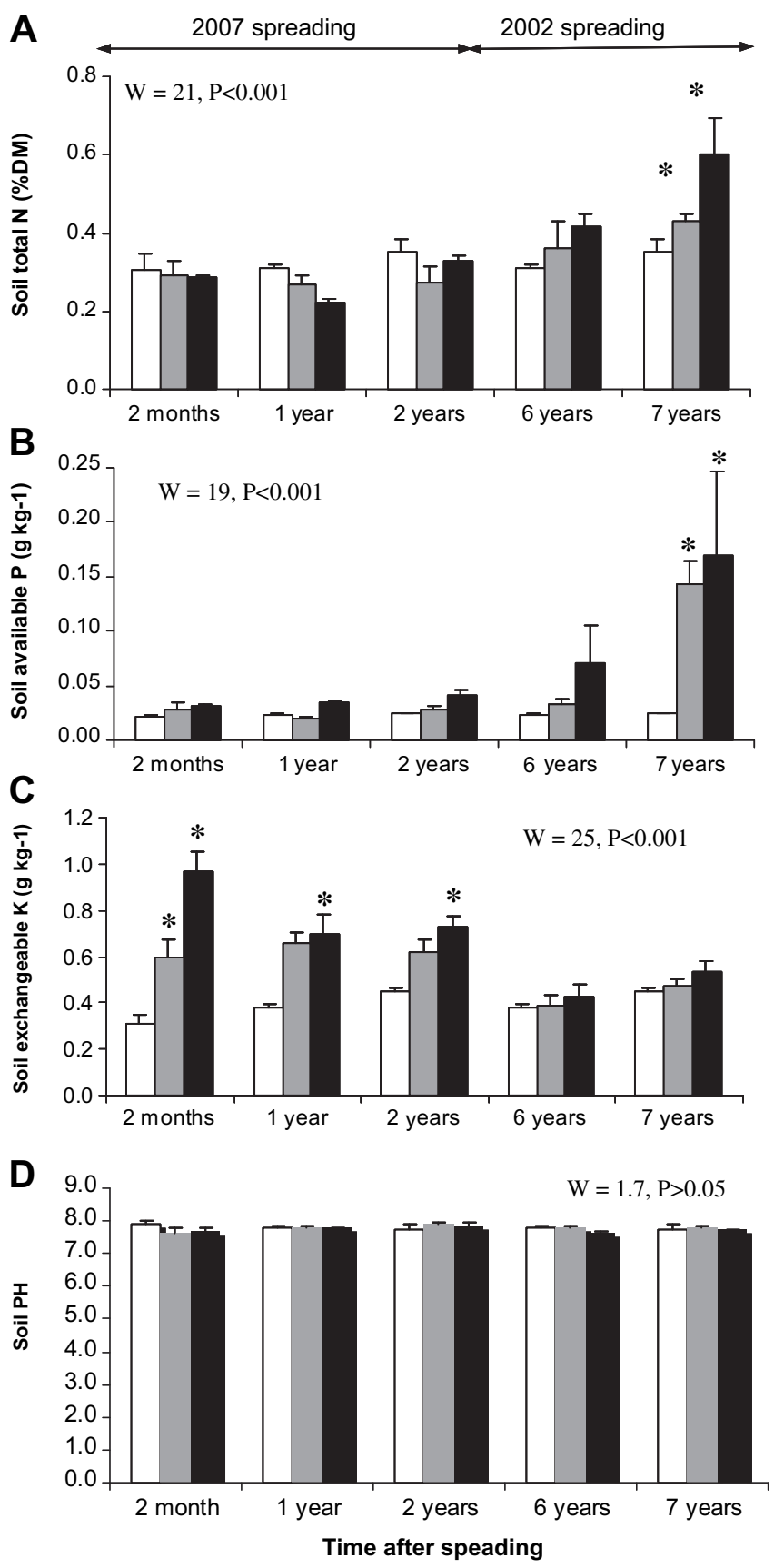

Fig. 2. Soil physical and chemical properties through treatments and time after compost spreading. A) total nitrogen, B) available phosphorus C) exchangeable potassium and D) pH. White column: control plots, grey: D50 plots, black: D100 plots. Error bars represent the standard error $(n=3)$. *: significantly different from the control $(P<0.05$, Student-Newman-Keuls non-parametric tests after Kruskal-Wallis test). 


\subsection{Modelling vegetation changes on stand emission level}

In order to assess for indirect changes in BVOC emissions from compost enrichment, we used the generic, process-based model for vegetation dynamics, SIERRA (Mouillot et al., 2001) coupled with a BVOC emission module as described in Lavoir et al. (2011). Briefly, SIERRA simulates annual leaf and biomass on the basis of plant water budget and specific water use efficiency (WUE). From leaf DM and LMA data, we estimated leaf area index (LAI) and BVOC emissions on a $1 / 2$ hourly basis as a response to light and temperature according to empirical equations shown in Guenther et al. (1993). In the simulation we assumed that compost spreading increased WUE $(+7 \%)$ and the percentage of carbon allocated to leaves, on the basis of the observed twig growth.

\subsection{Statistical analyses}

Data obtained from each sampling are presented as a function of time after compost spreading. Data of all plots with the same treatment were statistically checked for homogeneity. Since this was the case, we assumed that soil conditions and meteorology were homogeneous among plots. Therefore, the data obtained from the 3 year measurements in the plots of the two blocks treated in 2002 and 2007 were pooled and considered as a single time series representing 2 months, 1, 2, 5, 6 and 7 years after spreading. Repeated-measurement analyses (two-way within subject ANOVA; von Ende, 2001) were performed when comparing variables between non-independent individuals to test the effect of compost on $E$ and $E s$, BVOC and leaf nutrient content. One-way ANOVA was used to test the effect of compost on growth parameters. When data did not meet ANOVA postulates of normality (even after transformation) and homocedasticity (e.g. soil properties), a Kruskal-Wallis test was applied. Tukey test was used after ANOVAs and Student-Newman-Keuls non-parametric test was used after Kruskal-Wallis test. All tests were performed using Statistical Graphics XV Centurion.

\section{Results}

\subsection{Soil and leaf nutrients}

Soil total $\mathrm{N}$ and available P content was significantly increased by compost only 7 years after spreading, while exchangeable $\mathrm{K}$ concentration increased from the 2 first months, and reached initial values after 6 years (Fig. 2). Soil nutrient content in D50 and D100 plots was similar $(P>0.05)$. Soil $\mathrm{pH}$ varied between 7.64 and 7.91 , in agreement with compost $\mathrm{pH}$ which had a value of 7.7 (Larchevêque et al., 2006). No differences between compost treatments $(1.5<W<5.7, P>0.05)$ and time $(3.5<W<6.9, P>0.05$, Fig. 2D $)$ were found.

No change in leaf $\mathrm{N}$ content occurred for either species within the 7 years (Table 1), while $P$ was persistently enhanced from 5 years after spreading in $R$. officinalis and $C$. albidus leaves (Table $1, P<0.001$ ). Compost quickly enhanced leaf $\mathrm{K}$ in $R$. officinalis and $C$. albidus, from the first year $(P<0.01$ and $P<0.001$, respectively), but this effect was relatively short. None of the 3 leaf nutrients investigated was affected by compost in $Q$. coccifera. Values in D50 and D100 plots were never significantly different in all species $(P>0.05)$.

\subsection{Growth}

Growth of all species was significantly promoted by compost with no differences between D50 and D100 (Table 2), with the exception of for $C$. albidus where leaf DM was significantly higher in D100 than in D50 7 years after spreading. Generally, compost enhanced the number of leaves in C. albidus, and the leaf DM in all species with the exception of $R$. officinalis. The number of ramifications increased in $R$. officinalis and $Q$. coccifera. All species produced more wood, except $Q$. coccifera, which however presented bigger stems. Total leaf biomass on the last growth unit of the twigs increased by more than $50 \%$ in C. albidus 7 years after spreading, and by more than $90 \%$ in $Q$. coccifera 2 years after spreading.

\subsection{BVOC emission and storage at leaf scale}

Nine monoterpenes were identified in $Q$. coccifera emissions, the majors being $\alpha$-pinene, limonene and $\beta$-myrcene. In $C$. albidus, we identified 13 monoterpenes with $\alpha$-pinene and $\beta$-myrcene as major compounds, plus 2 sesquiterpenes ( $\beta$-caryophyllene and $\alpha$-humulene) accounting for less than $3 \%$ of total emissions. Finally, 13 monoterpenes (major compounds limonene and $\alpha$-pinene) and 1 sesquiterpene ( $\beta$-caryophyllene, $<1 \%$ of total emissions) were identified in $R$. officinalis. Total $E$ varied widely with years from $3.42-9.44,3.30-$ 13.30 and $2.40-14.00 \mu \mathrm{g} . \mathrm{gDM}^{-1} \cdot \mathrm{h}^{-1}$ for $\mathrm{Q}$. coccifera, C. albidus and $R$. officinalis respectively. Es values were quite similar to $E$ values

Table 1

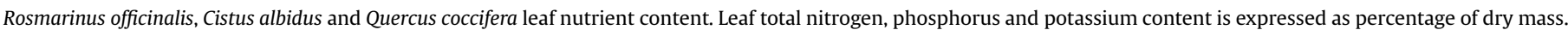
Values in brackets represent the standard error $(n=6$ to 7$)$. Asterisks denote a significant difference from the control.

\begin{tabular}{|c|c|c|c|c|c|c|c|c|c|c|}
\hline & \multirow{2}{*}{$\begin{array}{l}\text { Time after } \\
\text { spreading }\end{array}$} & \multicolumn{3}{|l|}{ R. officinalis } & \multicolumn{3}{|l|}{ C. albidus } & \multicolumn{3}{|l|}{ Q. coccifera } \\
\hline & & Control & D50 & D100 & Control & D50 & D100 & Control & D50 & D100 \\
\hline \multirow{6}{*}{$\mathrm{N}(\% \mathrm{DM})$} & 2 months & $0.80(0.06)$ & $0.80(0.02)$ & $0.87(0.04)$ & $0.98(0.03)$ & $1.03(0.08)$ & $0.97(0.05)$ & $1.00(0.02)$ & $1.02(0.01)$ & $1.06(0.04)$ \\
\hline & 1 year & $0.81(0.05)$ & $0.86(0.02)$ & $0.96(0.04)$ & $1.15(0.03)$ & $1.07(0.05)$ & $1.27(0.08)$ & $1.07(0.03)$ & $1.19(0.06)$ & $1.03(0.04)$ \\
\hline & 2 years & $0.94(0.03)$ & $0.93(0.05)$ & $1.00(0.08)$ & $1.01(0.04)$ & $0.94(0.02)$ & $0.99(0.07)$ & $1.00(0.08)$ & $0.93(0.01)$ & $0.96(0.02)$ \\
\hline & 5 years & $0.80(0.06)$ & $0.85(0.05)$ & $0.81(0.05)$ & $0.98(0.03)$ & $0.94(0.05)$ & $0.97(0.05)$ & $1.00(0.02)$ & $1.04(0.09)$ & $1.04(0.04)$ \\
\hline & 6 years & $0.81(0.05)$ & $0.83(0.05)$ & $0.80(0.05)$ & $1.15(0.03)$ & $1.09(0.03)$ & $1.24(0.07)$ & $1.07(0.03)$ & $1.04(0.03)$ & $1.17(0.05)$ \\
\hline & 7 years & $0.94(0.03)$ & $0.87(0.02)$ & $0.94(0.07)$ & $1.01(0.04)$ & $0.90(0.03)$ & $0.93(0.05)$ & $1.00(0.08)$ & $0.91(0.05)$ & $0.88(0.07)$ \\
\hline \multirow{6}{*}{$\mathrm{P}(\% \mathrm{DM})$} & 2 months & $0.057(0.005)$ & $0.051(0.002)$ & $0.057(0.004)$ & $0.081(0.002)$ & $0.082(0.005)$ & $0.083(0.003)$ & $0.048(0.002)$ & $0.047(0.002)$ & $0.052(0.002)$ \\
\hline & 1 year & $0.042(0.002)$ & $0.061(0.003)^{*}$ & $0.072(0.004)^{*}$ & $0.083(0.005)$ & $0.093(0.007)$ & $0.117(0.007)$ & $0.051(0.002)$ & $0.059(0.002)$ & $0.048(0.002)$ \\
\hline & 2 years & $0.054(0.002)$ & $0.072(0.004)$ & $0.074(0.009)$ & $0.106(0.006)$ & $0.137(0.011)$ & $0.126(0.013)$ & $0.045(0.002)$ & $0.051(0.005)$ & $0.049(0.004)$ \\
\hline & 5 years & $0.057(0.005)$ & $0.100(0.010)^{*}$ & $0.080(0.002)$ & $0.081(0.002)$ & $0.153(0.013)^{*}$ & $0.147(0.011)^{*}$ & $0.048(0.002)$ & $0.049(0.001)$ & $0.057(0.004)$ \\
\hline & 6 years & $0.042(0.002)$ & $0.075(0.002)^{*}$ & $0.081(0.008)^{*}$ & $0.083(0.005)$ & $0.167(0.016)^{*}$ & $0.157(0.016)^{*}$ & $0.051(0.002)$ & $0.051(0.002)$ & $0.057(0.004)$ \\
\hline & 7 years & $0.054(0.002)$ & $0.142(0.013)^{*}$ & $0.093(0.008)^{*}$ & $0.106(0.006)$ & $0.189(0.012)^{*}$ & $0.190(0.012)^{*}$ & $0.045(0.002)$ & $0.053(0.003)$ & $0.052(0.002)$ \\
\hline \multirow{6}{*}{ K (\% DM) } & 2 months & $1.00(0.09)$ & $1.15(0.05)$ & $1.15(0.18)$ & $0.55(0.01)$ & $0.57(0.04)$ & $0.60(0.02)$ & $0.44(0.03)$ & $0.50(0.02)$ & $0.54(0.03)$ \\
\hline & 1 year & $0.90(0.11)$ & $1.20(0.07)$ & $1.28(0.04)^{*}$ & $0.53(0.02)$ & $0.68(0.03)^{*}$ & $0.83(0.02)^{*}$ & $0.49(0.05)$ & $0.54(0.01)$ & $0.49(0.04)$ \\
\hline & 2 years & $1.16(0.07)$ & $1.26(0.001)$ & $1.31(0.07)$ & $0.66(0.03)$ & $0.71(0.05)$ & $0.65(0.03)$ & $0.45(0.04)$ & $0.52(0.05)$ & $0.54(0.05)$ \\
\hline & 5 years & $1.00(0.09)$ & $1.19(0.05)$ & $1.27(0.06)$ & $0.55(0.01)$ & $0.56(0.01)$ & $0.59(0.02)$ & $0.44(0.03)$ & $0.52(0.03)$ & $0.52(0.05)$ \\
\hline & 6 years & $0.90(0.11)$ & $1.01(0.09)$ & $1.12(0.08)$ & $0.53(0.02)$ & $0.63(0.03)$ & $0.67(0.03)$ & $0.49(0.05)$ & $0.44(0.04)$ & $0.52(0.05)$ \\
\hline & 7 years & $1.16(0.07)$ & $1.28(0.02)$ & $1.08(0.06)$ & $0.66(0.03)$ & $0.65(0.03)$ & $0.71(0.04)$ & $0.45(0.04)$ & $0.50(0.07)$ & $0.50(0.05)$ \\
\hline
\end{tabular}


Table 2

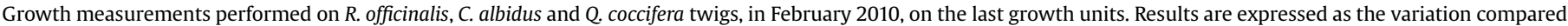

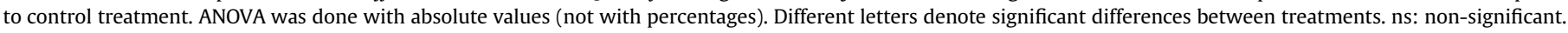
$\mathrm{nm}$ : not measured.

\begin{tabular}{|c|c|c|c|c|}
\hline Time after spreading & Dose & R. officinalis & C. albidus & Q. coccifera \\
\hline \multicolumn{5}{|l|}{ Stem dry mass (variation compared to control (\%)) } \\
\hline \multirow[t]{3}{*}{ (1) } & Control & $0^{\mathrm{a}}$ & $0^{\mathrm{a}}$ & 0 \\
\hline & D50 & $51^{\mathrm{ab}}$ & $38^{\mathrm{ab}}$ & 65 \\
\hline & D100 & $69^{\mathrm{b}}$ & $86^{\mathrm{b}}$ & 92 \\
\hline \multirow[t]{2}{*}{7 years } & D50 & $44^{\mathrm{ab}}$ & $88^{\mathrm{bc}}$ & 17 \\
\hline & D100 & $63^{\mathrm{b}}$ & $156^{\mathrm{c}}$ & -10 \\
\hline \multicolumn{5}{|l|}{ Stem volume (variation compared to control (\%)) } \\
\hline \multirow{3}{*}{2 years } & Control & $0^{\mathrm{a}}$ & $0^{\mathrm{a}}$ & $0^{\mathrm{ab}}$ \\
\hline & D50 & $33^{\mathrm{ab}}$ & $68^{\mathrm{ab}}$ & $68^{\mathrm{bb}}$ \\
\hline & D100 & $67^{\mathrm{b}}$ & $154^{\mathrm{bc}}$ & $127^{c}$ \\
\hline \multirow[t]{2}{*}{7 years } & D50 & $30^{\mathrm{ab}}$ & $149^{\mathrm{bc}}$ & $-36^{\mathrm{a}}$ \\
\hline & D100 & $86^{\mathrm{b}}$ & $232^{c}$ & $-23 a$ \\
\hline \multicolumn{5}{|l|}{ LMA } \\
\hline \multirow{3}{*}{2 years } & Control & 0 & 0 & 0 \\
\hline & D50 & 1 & -7 & 1 \\
\hline & D100 & 0 & -12 & -1 \\
\hline \multirow{2}{*}{7 years } & D50 & -3 & 1 & -7 \\
\hline & D100 & 1 & 11 & -8 \\
\hline \multicolumn{5}{|l|}{ Number of leaves on the last main axis (variation compared to control (\%)) } \\
\hline \multirow[t]{3}{*}{ (6) } & Control & 0 & $0^{\mathrm{a}}$ & 0 \\
\hline & D50 & 1 & $17^{\mathrm{ab}}$ & 21 \\
\hline & D100 & 11 & $13^{\mathrm{ab}}$ & 16 \\
\hline \multirow[t]{2}{*}{7 years } & D50 & 3 & $19^{\mathrm{b}}$ & 1 \\
\hline & D100 & 7 & $29^{b}$ & -1 \\
\hline \multicolumn{5}{|l|}{ Leaf dry Mass(variation compared to control (\%)) } \\
\hline \multirow[t]{3}{*}{ 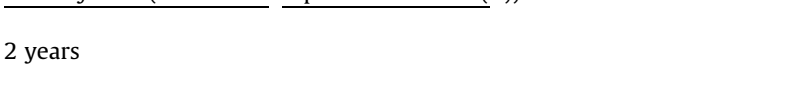 } & Control & 0 & $0^{\mathrm{a}}$ & $0^{\mathrm{a}}$ \\
\hline & D50 & 17 & $30^{\mathrm{ab}}$ & $55^{c}$ \\
\hline & D100 & 25 & $42^{\mathrm{ab}}$ & $40^{\mathrm{bc}}$ \\
\hline \multirow[t]{2}{*}{7 years } & D50 & 20 & $46^{\mathrm{b}}$ & $-10^{\mathrm{a}}$ \\
\hline & D100 & 18 & $93^{c}$ & $1^{\mathrm{ab}}$ \\
\hline \multirow[t]{2}{*}{ Number of ramifications on 2009 axis (variation compared to control (\%)) } & & & $\begin{array}{l}\text { Number of } \\
\text { axis }\end{array}$ & ns on 2008 \\
\hline & Control & $0^{\mathrm{a}}$ & 0 & $0^{\mathrm{a}}$ \\
\hline \multirow[t]{2}{*}{2 years } & D50 & $-4^{a}$ & 4 & $41^{\mathrm{ab}}$ \\
\hline & D100 & $14^{\mathrm{ab}}$ & 10 & $87^{b}$ \\
\hline \multirow[t]{2}{*}{7 years } & D50 & $16^{\mathrm{ab}}$ & 12 & $37^{\mathrm{ab}}$ \\
\hline & D100 & $26^{\mathrm{b}}$ & -18 & $7^{\mathrm{a}}$ \\
\hline \multicolumn{5}{|c|}{ Total leaf biomass on the last growth units of a twig (variation compared to control (\%)) } \\
\hline \multirow[t]{3}{*}{$e_{0}$} & Control & $\mathrm{nm}$ & $0^{\mathrm{a}}$ & $0^{\mathrm{a}}$ \\
\hline & D50 & $\mathrm{nm}$ & $26^{\mathrm{ab}}$ & $91^{\mathrm{b}}$ \\
\hline & D100 & $\mathrm{nm}$ & $57^{\mathbf{b}}$ & $118^{b}$ \\
\hline \multirow[t]{2}{*}{7 years } & D50 & $\mathrm{nm}$ & $71^{\mathrm{b}}$ & $16^{\mathrm{a}}$ \\
\hline & D100 & $\mathrm{nm}$ & $70^{\mathbf{b}}$ & $22^{\mathrm{a}}$ \\
\hline
\end{tabular}

(1.8-13.6, 1.1 to 5.1 and 1.6-6.9 $\mu$ g.gDM ${ }^{-1} \cdot \mathrm{h}^{-1}$ respectively, Fig. 3) and displayed similar patterns of variation with time after compost spreading. For both, $E$ and $E s$, there was no significant effect of compost probably due to the high intraspecific variability. Nevertheless, $E$ and Es from $R$. officinalis tended to increase in D100 plots 6 years after spreading $(P<0.1)$. Likewise, $E$ and $E$ s from $C$. albidus tended to be enhanced in D50 and D100 plots 7 years after spreading $(P<0.1)$. During all measurements, plant predawn water potential, which did not vary significantly with compost addition, never fell below $-2 \mathrm{MPa}$ for $Q$. coccifera and below $-4 \mathrm{MPa}$ for $C$. albidus and $R$. officinalis. No change in compound proportion was evidenced with compost and time, for any species $(P>0.1)$.

We identified 27 monoterpenes and 20 sesquiterpenes stored in $R$. officinalis leaves. The total amount ranged between 13 and $21 \mathrm{mg}$ $\mathrm{gDM}^{-1}$. In C. albidus leaves, 4 monoterpenes and 25 sesquiterpenes were identified with a total amount ranging between 120 and $380 \mu \mathrm{g} \mathrm{gDM}^{-1}$. Terpene content in $Q$. coccifera leaves was not studied because this species does not posses specific storage structures and, as a result, only insignificant terpene concentration occurs (Loreto et al., 2000). We observed no effect of compost on leaf terpene content in all species (Fig. 4). Terpene content in C. albidus was significantly lower in the measurements 1 and 2 years after spreading compared to the other dates (Fig. 4, $P<0.001)$. There was no correlation between $E_{S}$ and terpene content $(r<0.31, p>0.05)$, or between leaf nutrient content with either $E_{S}$ or terpene content $(r<0.10, r<0.25$ respectively), for total and single compounds.

\subsection{Assessment of terpene emissions at the ecosystem scale}

Estimation of stand level leaf biomass, wood biomass, LAI and BVOC emissions are presented in Table 3. Leaf biomass increased by $15-20 \%$, leading to a $16-19 \%$ increase in LAI, and in turn a $6.4-13.4 \%$ increase in BVOC emissions for the 3 studied species. This indirect compost effect therefore led to a significant increase in BVOC emissions at the stand level. 
A
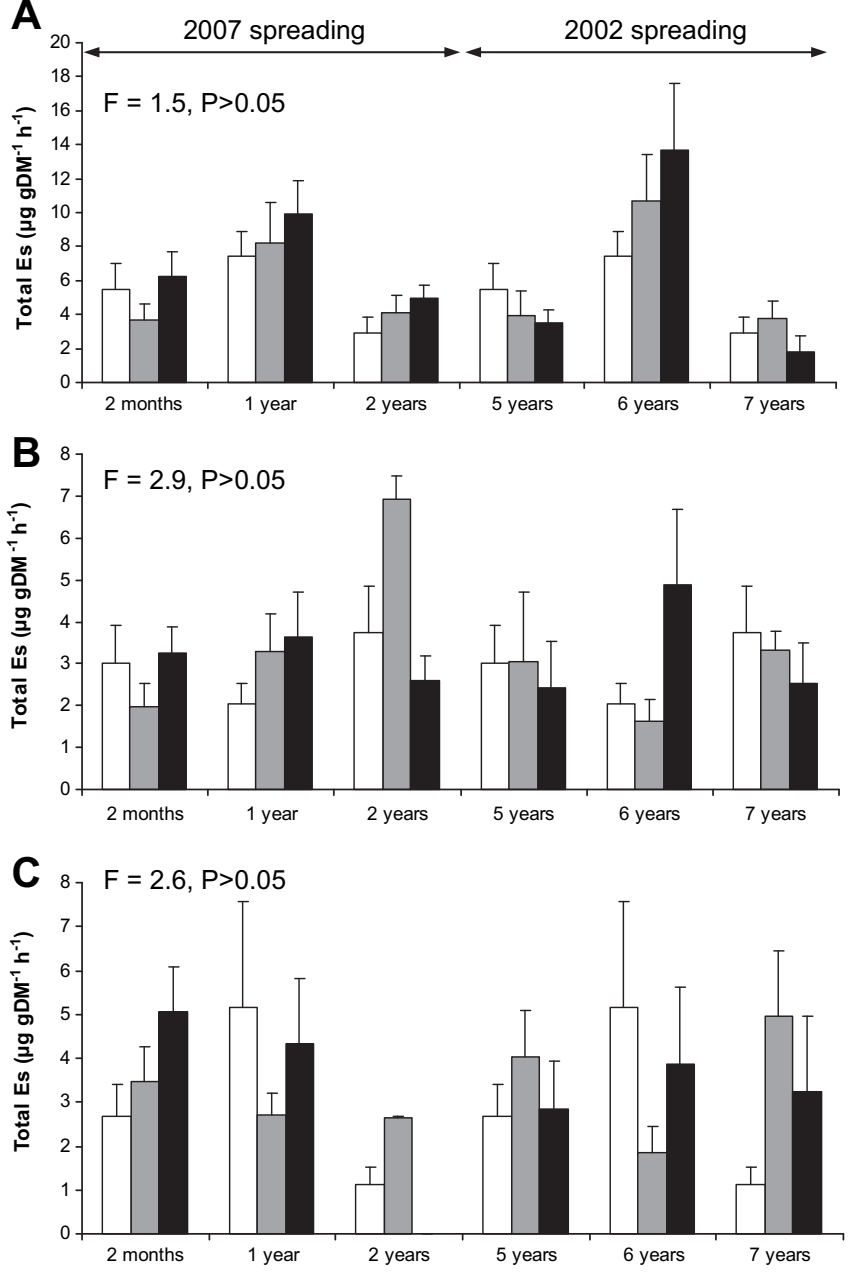

Fig. 3. Total terpene emission rate, normalized (Es) or not (E), at different times after compost spreading. A) Quercus coccifera, B) Rosmarinus officinalis and C) Cistus albidus White bars: controls (no treatment); grey bars: D50 treatment; black bars: D100 treatment. Error bars represent standard errors ( $n=6$ to 7$)$. nm: not measured.

\section{Discussion}

\subsection{Fertilizing effect of compost}

It is widely known that sewage sludge compost induces a fertilizing effect on vegetation and soil (Warman and Termeer, 2005; Larchevêque et al., 2006). However, in this study, positive effects of compost spreading on soil and leaf nutrient levels were moderate and often not significantly different from untreated control plots. A clear soil $\mathrm{N}$ increase could only be observed 7 years after spreading. Generally, the compost we used - a mix of sewage sludge and green waste with high $\mathrm{C} / \mathrm{N}$ ratios - slowly releases $\mathrm{N}$ to the soil. Consequently, within the time frame of this study, no increase in leaf $\mathrm{N}$ content occurred in either of the investigated species.

Although our compost is rich in $\mathrm{P}$, soil $\mathrm{P}$ content was not affected before the seventh year after spreading. This delay could be related to the formation of calcium-phosphate complexes, which decrease P solubility (Lambers et al., 1998). Moreover, summer drought in the Mediterranean region promotes $\mathrm{P}$ accumulation in the soil in forms that are not directly available to plants (Sardans and Peñuelas, 2004). Here, however, leaf $P$ content clearly increased from 5 years after compost spreading in $R$. officinalis and $C$. albidus leaves, suggesting possible root development close to the compost layer. Overall, in both terpene storing species, positive effects of

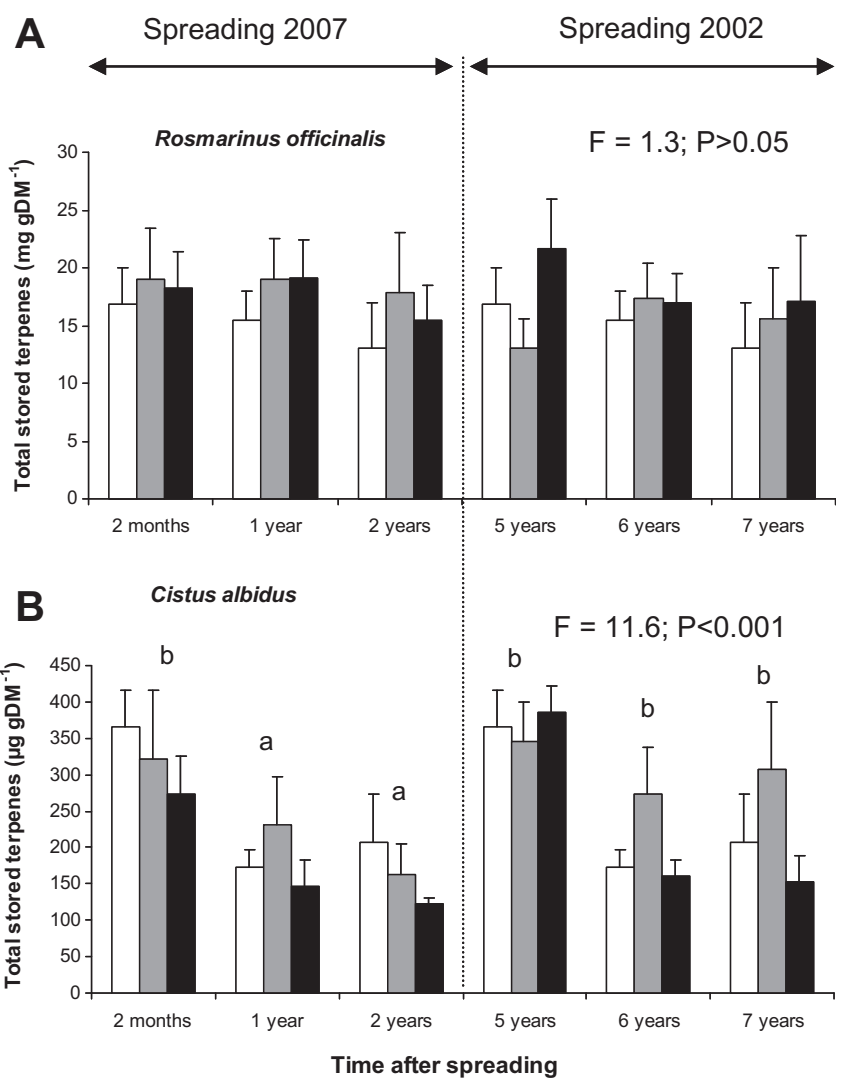

Fig. 4. Leaf total terpene content in Rosmarinus officinalis and Cistus albidus for control (white bars), D50 (grey bars) and D100 (black bars) plots. Error bars represent the standard error ( $n=6$ to 7). Different letters denote significant differences between sampling dates (two-way within subject ANOVA: $\mathrm{F}$ ). $\mathrm{F}$ and $P$ values are the results of tests performed on the 'time after spreading' variable. Compost had no significant effect on total terpene content $(F=1.7$ and $F=2.1$ for $R$. officinalis and $C$. albidus respectively). The grey line separates measurements done on 2007-spread plots (on the left) and 2002 spread plots (on the right).

compost on plant nutrient status were mostly seen in leaf $\mathrm{P}$ concentrations indicating that this element was limiting in the shrubland. Sardans et al. (2004) also observed the high responsiveness of Mediterranean plants to soil P.

Unlike $\mathrm{N}$ and $\mathrm{P}, \mathrm{K}$ leached to the mineral layer very quickly, as already reported by Larchevêque et al. (2006). This fertilizing effect was observed for a short 2-year period only, after which soil showed its initial $\mathrm{K}$ concentration. Accordingly, K only increased during the first year following spreading in $C$. albidus and

Table 3

Data obtained during simulation using SIERRA model for total biomass, Leaf biomass, LAI and BVOC emissions for R. officinalis, C. albidus and Q. coccifera.

\begin{tabular}{lllll}
\hline & $\begin{array}{l}\text { Wood biomass } \\
\left(\mathrm{mgC} \mathrm{m}^{-2}\right)\end{array}$ & $\begin{array}{l}\text { Leaf biomass } \\
\left(\mathrm{mgC} \mathrm{m}^{-2}\right)\end{array}$ & LAI & $\begin{array}{l}\text { VOC } \\
\left(\mathrm{mg} \mathrm{year}^{-1} \mathrm{~m}^{-2}\right)\end{array}$ \\
\hline Cistus albidus & & & & \\
No Compost & 838 & 78 & 0.44 & 1160 \\
With Compost & 941 & 89 & 0.51 & 1310 \\
Difference \% & $+12.4 \%$ & $+15.3 \%$ & $+16.4 \%$ & $+\mathbf{1 3 . 2 \%}$ \\
Quercus coccifera & & & & \\
No compost & 2700 & 276 & 2.08 & 9.60 \\
With Compost & 2830 & 322 & 2.42 & 1020 \\
Difference \% & $+3.6 \%$ & +16.5 & $16.5 \%$ & $+\mathbf{5 . 3 6 \%}$ \\
Rosmarinus officinalis & 1143 & & & \\
No compost & 162 & 0.82 & 1940 \\
With Compost & 1162 & 195 & 0.98 & 2200 \\
Difference \% & $+2 \%$ & $+20.3 \%$ & $+18.9 \%$ & $+\mathbf{1 3 . 6 \%}$ \\
\hline
\end{tabular}


$R$. officinalis leaves. $\mathrm{K}$ is especially important in dry environments due to its role in controlling leaf water loss, its relationship with osmotic requirements and favorable effect on photosynthesis (Milla et al., 2005; Mengel and Kirkby, 2001). Q. coccifera leaf nutrient content was not affected by compost. The low responsiveness of this species to nutrient supply may reflect a conservative resource use strategy resulting from an adaptation to Mediterranean soil and climate (Valladares et al., 2000).

Overall, leaf nutrient content of the 3 species was moderately affected by compost, over the 7 years following spreading. In general, species adapted to nutrient-poor environments have a lower capacity to increase nutrient uptake and storage in response to sudden nutrient supplies than species adapted to rich environments (Chapin et al., 1986). Nevertheless, growth of all species was increased by compost from the second year onwards, indicating that soil properties were improved by compost spreading. Possibly, all species used the improved availability of nutrients to generate new biomass without accumulation of nutrients inside leaves, thus explaining the absence of significant changes in leaf nutrient content by compost spreading (Slesak and Briggs, 2010). Moreover, the possibility that changes in wood nutrient content occurred cannot be ruled out.

\subsection{Terpene content and emission}

Terpene stored amounts were within the range of previous studies, namely $100-400 \mu \mathrm{gDM}^{-1}$ for $C$. albidus (Llusià and Peñuelas, 2000) and $10-20 \mathrm{mg} \mathrm{gDM}^{-1}$ for $R$. officinalis (Llusià et al., 2006). Over the 7 years of investigation, compost did not affect terpene content, in agreement with our previous results (Ormeño et al., 2009). Similarly, coniferous trees showed no alteration in needle terpene content after fertilization (Kainulainen et al., 1996; Blanch et al., 2009). However, Lerdau et al. (1995) found positive effects of fertilization on needle terpene content, mostly related to an increase in leaf $\mathrm{N}$ concentration, which was not observed in our study. Besides, the decline in total terpene content observed in C. albidus in all treatments in 2008 and 2009 was probably due to different summer conditions in 2007, rather than to a potential compost effect, since this decreasing trend could also be observed in the 2002 spread plots, i.e. both 2 and 5 years after spreading. June 2008 and 2009 were indeed particularly dry (17 mm of total precipitation, Fig. 5) compared to June 2007 (34 mm of total precipitation). Although terpene content was generally found to increase in response to moderate drought conditions (Delfine et al., 2005; Blanch et al., 2009), a negative effect of drought on C. albidus has already been observed (Llusià et al., 2010).

An increase in nutrient assimilation often promotes BVOC emissions (Peñuelas and Staudt, 2010) due to increases in leaf $\mathrm{N}$ concentration (Lerdau et al., 1995), although this pattern varies among plant species (Rosenstiel et al., 2004; Blanch et al., 2007). Consistently with the absence of changes in leaf $\mathrm{N}$ content, we did not observe any compost effect on terpene emissions from $Q$. coccifera. Nevertheless, BVOC emissions from $R$. officinalis and C. albidus tended to increase after 6 and 7 years of compost spreading respectively, coinciding with increases in leaf $P$ content. The few studies that have tested the effect of P on BVOC emissions (Blanch et al., 2007; Fares et al., 2008) found no or negative effects. Since terpene precursors contain high-energy phosphate bonds and require ATP and NADPH for their synthesis (Lichtenthaler, 1999), additional $\mathrm{P}$ supply may sustain terpene biosynthesis in plants growing in nutrient-poor soils, as partly indicated by our results.

In addition to changes in nutrient availability, compost spreading may affect water availability by increasing water retention and reducing evaporation and surface run off. Severe drought is known to negatively affect monoterpene and sesquiterpene
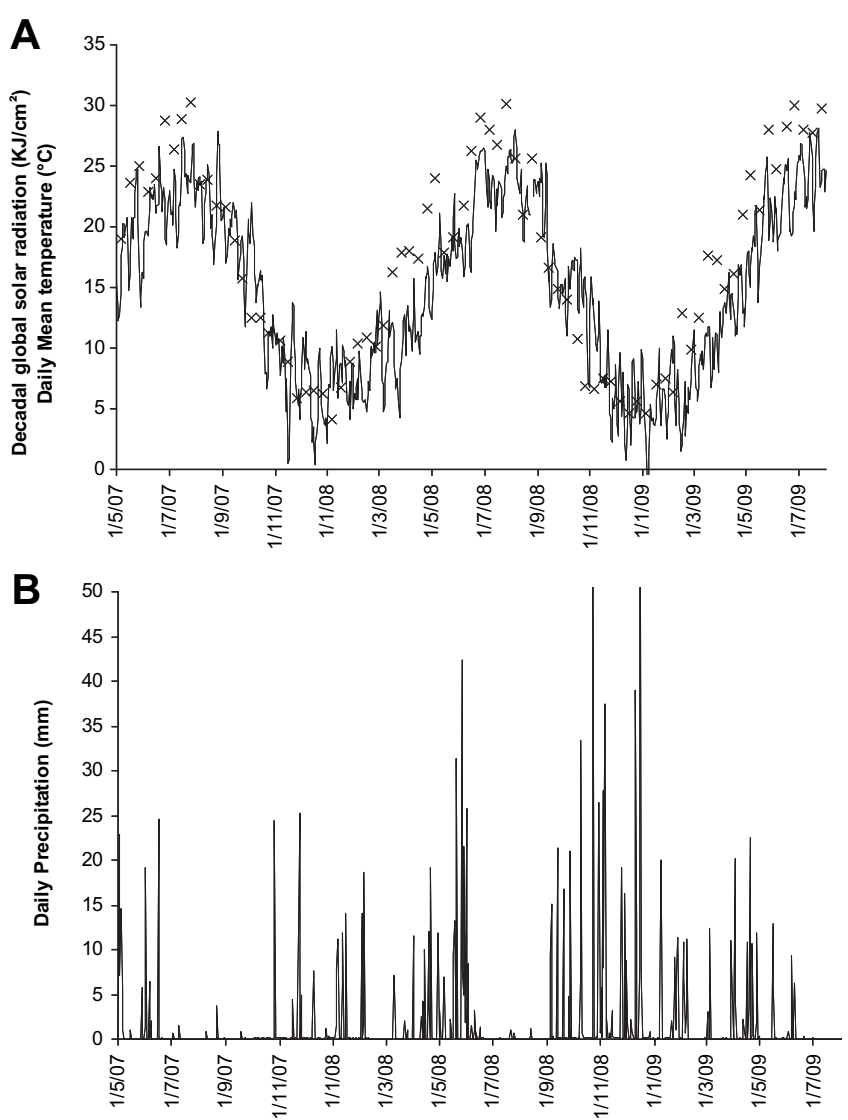

Fig. 5. Climatic conditions observed at the site during the study period. A) Mean daily temperature $\left({ }^{\circ} \mathrm{C}\right)$ and decadal solar radiation $\left(\mathrm{kJ} \mathrm{cm}^{-2}\right)$; B) Mean daily precipitation $(\mathrm{mm})$.

emissions from both storing and non-terpene storing species (Staudt et al., 2002; Lavoir et al., 2009; Llusià et al., 2010). However, in this study compost did not improve plant water status during the measurement periods and also had no effect on VOC emission rates.

Generally, mycorrhiza improves the ability for nutrient acquisition by plants (Palenzuela et al., 2002), a factor that affects BVOC emissions (Blanch et al., 2007). We explored the possibility that mycorrhiza associations may explain our results: compost slightly affected $C$. albidus and $R$. officinalis (emissions and nutrition) whereas no effect was found for $Q$. coccifera. It appears however unlikely that these biotic associations were responsible for these differences since $Q$. coccifera and $C$. albidus share the same ectomycorrhizal association (Watson et al., 1990; Comandini and Contu, 2006) while R. officinalis features endomycorrhiza (Sanchez-Blanco et al., 2004). Furthermore, soil organic amendment has no clear effect on mycorrhizae associations (Bastida et al., 2008; Rincón et al., 2006). Finally, Rapparini et al. (2008) showed that mycorrhiza does not significantly alter either monoterpene emission or content.

\subsection{Compost spreading enhances plant growth: consequences for BVOC fluxes}

As compost increased total leaf biomass on the last growth units by more than $50 \%$ in C. albidus and around $100 \%$ in Q. coccifera, depending on the exposure time, we expected increases in BVOC emissions at the stand scale. This was supported by modeling simulations which showed an increase of BVOC emission at stand level of about $6-13 \%$ depending on the species (Table 3 ). Compost spreading enhanced BVOC emissions by $1.1 \mathrm{~kg} \mathrm{ha}^{-1} \mathrm{y}^{-1}$ in the 
investigated shrubland dominated by $Q$. coccifera. This value can even reach $2.1 \mathrm{~kg} \mathrm{ha}^{-1} \mathrm{y}^{-1}$ in a typical shrubland dominated by C. albidus and $2.6 \mathrm{~kg} \mathrm{ha}^{-1} \mathrm{y}^{-1}$ for a typical shrubland dominated by $R$. officinalis ( 2 other typical garrigues observed in the Mediterranean region).

\section{Conclusion}

We studied terpene emission and content from 3 shrub species in a natural Mediterranean garrigue, 2 months to 7 years after compost spreading. Our results suggest that compost spreading may only weakly affect BVOC emissions at the leaf level, consistently with the weak effect on foliar nutrient content found. However, at the stand level, compost spreading may indirectly increase VOC emissions through biomass enhancement, a result to be considered when assessing the environmental impact of this waste recycling practice.

\section{Acknowledgment}

We thank Sylvie Dupouyet, Caroline Lecareux for field sampling and growth measurements, Jean-Marc Ourcival (CEFE-CNRS) for his valuable advice for growth measurements and Michael Paul for English improvement. This study was funded in part by ADEME ( $\left.{ }^{\circ} 0575 \mathrm{C0004}\right)$ and Provence Alpes Côte-d’Azur Region.

\section{References}

Archibold, O.W., 1995. Mediterranean Ecosystems, Ecology of World Vegetation. Chapman et Hall, London, UK.

Atkinson, R., Arey, J., 2003. Gas-phase tropospheric chemistry of biogenic volatile organic compounds: a review. Atmospheric Environment 37, S197-S219.

Bastida, F., Kandeler, E., Moreno, J.L., Ros, M., Garcia, C., Hernandez, T., 2008. Application of fresh and composted organic wastes modifies structure, size and activity of soil microbial community under semiarid climate. Applied Soil Ecology 40, 318-329.

Blanch, J.S., Peñuelas, J., Llusià, J., 2007. Sensitivity of terpene emissions to drought and fertilization in terpene-storing Pinus halepensis and non-storing Quercus ilex. Physiologia Plantarum 131, 211-225.

Blanch, J.S., Peñuelas, J., Sardans, J., Llusià, J., 2009. Drought, warming and soil fertilization effects on leaf volatile terpene concentrations in Pinus halepensis and Quercus ilex. Acta Physiologiae Plantarum 31, 207-218.

Chapin, F.S., Vitousek, P.M., Vancleve, K., 1986. The nature of nutrient limitation in plant-communities. American Naturalist 127, 48-58.

Comandini, O., Contu, M., 2006. An overview of Cistus ectomycorrhizal fungi. Mycorrhiza 16, 381-395.

Delfine, S., Loreto, F., Pinelli, P., Tognetti, R., Alvino, A., 2005. Isoprenoids content and photosynthetic limitations in rosemary and spearmint plants under water stress. Agriculture Ecosystems \& Environment 106, 243-252.

European Environment Agency, 2009. Air pollution by ozone across Europe during summer 2008. Overview of exceedances of EC ozone threshold values for April-September 2008. EEA Technical report No 2, Copenhagen K.

Fares, S., Brilli, F., Nogues, I., Velikova, V., Tsonev, T., Dagli, S., Loreto, F., 2008. Isoprene emission and primary metabolism in Phragmites australis grown under different phosphorus levels. Plant Biology 10, 38-43.

Fuentes, D., Valdecantos, A., Cortina, J., Vallejo, V.R., 2007. Seedling performance in sewage sludge-amended degraded mediterranean woodlands. Ecological Engineering 31, 281-291.

García, C., Hernández, T., Costa, F., 1990. The influence of composting and maturation processes on the heavy-metal extractability from some organic wastes. Biological Wastes 31, 291-301.

Grogan, P., Bruns, T.D., Chapin, F.S., 2000. Fire effects on ecosystem nitrogen cycling in a Californian bishop pine forest. Oecologia 124, 622 .

Guenther, A.B., Zimmerman, P.R., Harley, P.C., Monson, R.K., Fall, R., 1993. Isoprene and monoterpene emission rate variability - model evaluations and sensitivity analyses. Journal of Geophysical Research-Atmospheres 98, 12609-12617.

Heyworth, C.J., Iason, G.R., Temperton, V., Jarvis, P.G., Duncan, A.J., 1998. The effect of elevated $\mathrm{CO}_{2}$ concentration and nutrient supply on carbon-based plant secondary metabolites in Pinus sylvestris L. Oecologia 115, 344-350.

Hussein, M.S., Ei-Sherbeny, S.E., Khalil, M.Y., Naguib, N.Y., Aly, S.M., 2006. Growth characters and chemical constituents of Dracocephalum moldavica L plants in relation to compost fertilizer and planting distance. Scientia Horticulturae 108, 322-331.

Kainulainen, P., Holopainen, J., Palomaki, V., Holopainen, T., 1996. Effects of nitrogen fertilization on secondary chemistry and ectomycorrhizal state of Scots pine seedlings and on growth of grey pine aphid. Journal of Chemical Ecology 22, 617-636.
Lambers, H., Chapin, I.F.S., Pons, T.L., 1998. Plant Physiological Ecology. SpringerVerlag, New York.

Larchevêque, M., Baldy, V., Montes, N., Fernandez, C., Bonin, G., Ballini, C., 2006 Short-term effects of sewage-sludge compost on a degraded Mediterranean soil. Soil Science Society of America Journal 70, 1178-1188.

Larchevêque, M., Ballini, C., Baldy, V., Korboulewsky, N., Ormeño, E., Montès, N. 2009. Restoration of a mediterranean postfire shrubland: plant functional responses to organic soil amendment. Restoration Ecology, 1-13.

Lavoir, A.-V., Mouillot, F., Duffet, C., Rambal, S., Ratte, J.-P., Schnitzler, J.-P., Staudt, M. 2011. Scaling up monoterpene emissions from a water limited quercus ilex woodland. Atmospheric Environment 45 (17), 2888-2897.

Lavoir, A.V., Staudt, M., Schnitzler, J.P., Landais, D., Massol, F., Rocheteau, A, Rodriguez, R., Zimmer, I., Rambal, S., 2009. Drought reduced monoterpene emissions from the evergreen Mediterranean oak Quercus ilex: results from a throughfall displacement experiment. Biogeosciences 6, 1167-1180.

Leirós, M.C., Trasar-Cepeda, C., Seoane, S., Gil-Sotres, F., 1999. Dependence of mineralization of soil organic matter on temperature and moisture. Soil Biology and Biochemistry 31, 327-335.

Lerdau, M., Matson, P., Fall, R., Monson, R., 1995. Ecological controls over monoterpene emissions from Douglas-fir (Pseudotsuga-Menziesii). Ecology 76, 2640-2647.

Lichtenthaler, H.K., 1999. The 1-deoxy-D-xylulose-5-phosphate pathway of isoprenoid biosynthesis in plants. Annual Review of Plant Physiology and Plant Molecular Biology 50, 47-65.

Litvak, M.E., Constable, J.V.H., Monson, R.K., 2002. Supply and demand processes as controls over needle monoterpene synthesis and concentration in Douglas fir [Pseudotsuga menziesii(Mirb.) Franco]. Oecologia 132, 382-391.

Llusià, J., Peñuelas, J., 2000. Seasonal patterns of terpene content and emission from seven Mediterranean woody species in field conditions. American Journal of Botany 87, 133-140.

Llusià, J., Peñuelas, J., Alessio, G.A., Estiarte, M., 2006. Seasonal contrasting changes of foliar concentrations of terpenes and other volatile organic compound in four dominant species of a Mediterranean shrubland submitted to a field experimental drought and warming. Physiologia Plantarum 127, 632-649.

Llusià, J., Peñuelas, J., Ogaya, R., Alessio, G., 2010. Annual and seasonal changes in foliar terpene content and emission rates in Cistus albidus L. submitted to soil drought in Prades forest (Catalonia, NE Spain). Acta Physiologiae Plantarum 32, 387-394.

Loreto, F., Ciccioli, P., Brancaleoni, E., Frattoni, M., Delfine, S., 2000. Incomplete C-13 labelling of alpha-pinene content of Quercus ilex leaves and appearance of unlabelled $\mathrm{C}$ in alpha-pinene emission in the dark. Plant Cell and Environment 23, 229-234.

Martinez, F., Cuevas, G., Calvo, R., Walter, I., 2003. Biowaste effects on soil and native plants in a semiarid ecosystem. Journal of Environmental Quality 32, 472-479.

Mengel, K., Kirkby, E.A., 2001. Principles of Plant Nutrition, fifth ed. Kluwer Academic Publishers, Dordrecht.

Milla, R., Castro, D.P., Maestro, M.M., Monrserrat, M.G., 2005. Relationships Between Phenology and the Remobilization of Nitrogen, Phosphorus and Potassium in Branches of Eight Mediterranean Evergreens. Blackwell, Oxford, United Kingdom.

Misson, L., Degueldre, D., Collin, C., Rodriguez, R., Rocheteau, A., Ourcival, J.M. Rambal, S., 2011. Phenological responses to extreme droughts in a Mediterranean forest. Global Change Biology 17, 1036-1048.

Mouillot, F., Rambal, S., Lavorel, S., 2001. A generic process-based SImulator for meditERRanean landscApes (SIERRA): design and validation exercises. Forest Ecology and Management 147, 75-97.

MSI reports, 2007. Le Recyclage des Boues d'Assainissement des Eaux Usées en France. MSI Reports Ltd, Lyon.

Navas, A., Machín, J., Navas, B., 1999. Use of biosolids to restore the natura vegetation cover on degraded soils in the badlands of Zaragoza (NE Spain). Bioresource Technology 69, 199-205.

Niinemets, U., Hauff, K., Bertin, N., Tenhunen, J.D., Steinbrecher, R., Seufert, G., 2002 Monoterpene emissions in relation to foliar photosynthetic and structural variables in Mediterranean evergreen Ouercus species. New Phytologist 153, 243-256.

Niinemets, U., Loreto, F., Reichstein, M., 2004. Physiological and physicochemical controls on foliar volatile organic compound emissions. Trends in Plant Science 9, 180-186.

Olivier, R., Staudt, M., Lavoir, A.V., Ormeño, E., Rizvi, H., Baldy, V., Rivoal, A., Greff, S. Lecareux, C., Fernandez, C., 2011. Direct and indirect impact of sewage sludge compost spreading on Quercus coccifera monoterpene emissions in a Mediterranean shrubland. Environmental Pollution, doi:101016/j.envpol 201012.003.

Ormeño, E., Fernandez, C., Bousquet-Mélou, A., Greff, S., Morin, E., Robles, C., Vila, B. Bonin, G., 2007a. Monoterpene and sesquiterpene emissions of four typical Mediterranean species, through calcareous and siliceous soils in south of France. Atmospheric Environment 41, 629-639.

Ormeño, E., Fernandez, C., Mevy, J.P., 2007b. Plant coexistence alters terpene emission and content of Mediterranean species. Phytochemistry 68, 840-852.

Ormeño, E., Olivier, R. Mévy, J.P., Baldy, V., Fernandez, C., 2009. Compost may affect volatile and semi-volatile plant emissions through nitrogen supply and chlorophyll fluorescence. Chemosphere 77, 94-104.

Owen, S.M., Boissard, C., Nicholas Hewitt, C., 2001. Volatile organic compounds (VOCs) emitted from 40 VOC speciation and extrapolation to habitat scale. Atmospheric Environment 35, 5393-5409.

Palenzuela, J., Azcon-Aguilar, C., Figueroa, D., Caravaca, F., Roldan, A., Barea, J.M., 2002 Effects of mycorrhizal inoculation of shrubs from Mediterranean ecosystems and composted residue application on transplant performance and mycorrhiza developments in a desertified soil. Biology and Fertility of Soils 36, 170-175. 
Peñuelas, J., Staudt, M., 2010. BVOCs and global change. Trends in Plant Science 15, 133-144.

Possell, M., Heath, J., Nicholas Hewitt, C., Ayres, E., Kerstiens, G., 2004. Interactive effects of elevated $\mathrm{CO}_{2}$ and soil fertility on isoprene emissions from Quercus robur. Global Change Biology 10, 1835-1843.

Rapparini, F., Llusia, J., Penuelas, J., 2008. Effect of arbuscular mycorrhizal (AM) colonization on terpene emission and content of Artemisia annua L. Plant Biology 10, 108-122.

Rincón, A., Ruiz-Diez, B., Fernandez-Pascual, M., Probanza, A., Pozuelo, J.M., de Felipe, M.R., 2006. Afforestation of degraded soils with Pinus halepensis Mill.: effects of inoculation with selected microorganisms and soil amendment on plant growth, rhizospheric microbial activity and ectomycorrhizal formation. Applied Soil Ecology 34, 42-51.

Rosenstiel, T.N., Ebbets, A.L., Khatri, W.C., Fall, R., Monson, R.K., 2004. Induction of poplar leaf nitrate reductase: a test of extrachloroplastic control of isoprene emission rate. Plant Biology 6, 12-21.

Sanchez-Blanco, M.J., Ferrandez, T., Navarro, A., Banon, S., Alarçon, A., 2004. Effects of irrigation and air humidity preconditioning on water relations, growth and survival of Rosmarinus officinalis plants during and after transplanting. Journa of Plant Physiology 161, 1133-1142.

Sardans, J., Peñuelas, J., 2004. Increasing drought decreases phosphorus availability in an evergreen Mediterranean forest. Plant and Soil 267, 367-377.

Sardans, J., Roda, F., Peñuelas, J., 2004. Phosphorus limitation and competitive capacities of Pinus halepensis and Quercus ilex subsp rotundifolia on different soils. Plant Ecology 174, 305-317.

Slesak, R.A., Briggs, R.D., 2010. Foliar mass and nutrition of Abies concolor christmas trees following application of organic and inorganic fertilizer. Northern Journal of Applied Forestry 27, 28-33.
Staudt, M., Jackson, B., El-Aouni, H., Buatois, B., Lacroze, J.-P., Poëssel, J.-L., Sauge, M.-H., 2010. Volatile organic compound emissions induced by the aphid Myzus persicae differ among resistant and susceptible peach cultivars and a wild relative. Tree Physiology 10, 1320-1334.

Staudt, M., Rambal, S., Joffre, R., Kesselmeier, J., 2002. Impact of drought on seasonal monoterpene emissions from Quercus ilex in southern France. Journal of Geophysical Research 107, 722-730.

Tanu, Prakash, A., Adholeya, A., 2004. Effect of different organic manures/composts on the herbage and essential oil yield of Cymbopogon winterianus and their influence on the native AM population in a marginal alfisol. Bioresource Technology 92, 311-319.

Valladares, F., Martinez-Ferri, E., Balaguer, L., Perez-Corona, E., Manrique, E., 2000. Low leaf-level response to light and nutrients in Mediterranean evergreen oaks: a conservative resource-use strategy? New Phytologist 148, 79-91.

Vaz, L.M.S., Goncalves, J.L.M., 2002. Use of biosolid in eucalypt stand: effect on soil chemical attributes, and growth and uptake nutrient by the trees. Revista Brasileira de Ciencia do Solo 26, 747-758.

Vickers, C.E., Gershenzon, J., Lerdau, M.T., Loreto, F., 2009. A unified mechanism of action for volatile isoprenoids in plant abiotic stress. Nature Chemical Biology 5, 283-291.

von Ende, C.N., 2001. Repeated-measures analysis. In: Scheiner, S.M., Gurevitch, J. (Eds.), Design and Analysis of Ecological Experiments. Oxford University Press, pp. 134-157.

Warman, P.R., Termeer, W.C., 2005. Evaluation of sewage sludge, septic waste and sludge compost applications to corn and forage: yields and $\mathrm{N}, \mathrm{P}$ and $\mathrm{K}$ content of crops and soils. Bioresource Technology 96, 955-961.

Watson, G.W., Von der Heide-Spavka, K.G., Howe, V.K., 1990. Ecological significance of endo/ectomycorrhiza in the oak sub-genus Erythrobalanus. Arboriculture Journal 14, 107-116. 